\title{
Comparative Study of Prolactin Levels in Acne and Non-Acne Individuals Among Students of College of Health Sciences, Nnamdi Azikiwe University, Nnewi, Nigeria
}

\author{
Emmanuel Okechukwu Chukwu ${ }^{1}$, Odunukwe Juliet Ifeoma ${ }^{1}$, Terkuma Chia ${ }^{1}$, \\ Ufearo Chibueze Stephen ${ }^{2}$, Ugbor Godwin Onyedikachi ${ }^{3}$ \\ ${ }^{1}$ School of Nursing Mkar, Gboko, Nigeria \\ ${ }^{2}$ Department of Physiology, College of Health Sciences, Nnamdi Azikiwe University, Nnewi, Nigeria \\ ${ }^{3}$ School of Midwifery Mkar, Gboko, Nigeria
}

Email address:

emmanwaguy42@yahoo.com (E. O. Chukwu)

\section{To cite this article:}

Emmanuel Okechukwu Chukwu, Odunukwe Juliet Ifeoma, Terkuma Chia, Ufearo Chibueze Stephen, Ugbor Godwin Onyedikachi. Comparative Study of Prolactin Levels in Acne and Non-Acne Individuals Among Students of College of Health Sciences, Nnamdi Azikiwe University, Nnewi, Nigeria. International Journal of Biomedical Engineering and Clinical Science. Vol. 3, No. 4, 2017 , pp. 25-31. doi: 10.11648/j.ijbecs.20170304.11

Received: February 22, 2017; Accepted: March 21, 2017; Published: October 18, 2017

\begin{abstract}
Prolactin (PRL) is well recognized for its role(s) in mammary gland development and function as well as over three hundred non-lactational functions. However, androgens have a main role in acne pathogenesis and the interaction between prolactin and androgens generate the hypothesis of prolactin role in acne pathogenesis. Therefore a difference should exist in the prolactin hormone levels of acne individuals in comparison with non-acne individuals. The aim of this study was to make assessment and comparison of serum hormonal levels of prolactin in acne vulgaris individuals and non-acne individuals. In this cross-sectional case control study, serum levels of prolactin were collected and estimated in 60 subjects consisting of 30 males and 30 females each; of which 15 were the control group and 15, the test group in each category respectively. Also certain criteria's were looked into such as subject's age, state of health, menstrual patterns (for females) and much more. Data collected was analyzed using the Software Package for Social Sciences (SPSS). At the end of the experiment, the result showed no significant change $(\mathrm{p}<0.05)$, however mean serum prolactin levels were significantly high among the acne cases in both the males $(12.26 \pm 1.50)$ when compared to the control of males $(8.80 \pm 1.03)$, and also acne cases of the females $(22.04 \pm 4.59)$ when compared to the control of the females $(12.92 \pm 1.62)$ females. A non-significant change in the comparism of serum prolactin levels of acne subjects and non-acne subjects in both males and females may be as result of the small sample size used. However, more powerful studies are needed. An increase in the mean serum prolactin levels of acne subjects in both categories when compared to non-acne subjects indicates the contribution of prolactin in the pathogenesis of acne.
\end{abstract}

Keywords: Comparative, Study, Prolactin, Levels, Acne, Non-Acne, Individuals

\section{Background of Study}

Acne vulgaris or acne remains one of the most common skin diseases afflicting humanity (Adityan and Thappa, 2009). It is a chronic inflammatory disease of the pilosebaceous units, clinically characterized by seborrhea, or grease production, comedones, papules, pustules, nodules and, in some cases, scarring (Thiboutot et al. 2009). In general terms, acne is characterized by sebum overproduction, follicular hyperkeratinization, and an increased release of inflammatory- mediating chemicals (Kurokawa et al, 2009).

It is a common condition with a wide range of potential harms and associated costs. The former include symptomatic discomfort, scarring, emotional and psychosocial distress, occupational consequences and potential psychiatric disturbances including depression and suicide (Barnes, Levenda, Flesher and Felman, 2012). Acne is estimated to affect $9 \cdot 4 \%$ of the global population, making it the eighth most prevalent disease worldwide (Tan \& Bhate 2015). Despite acne being an almost universal condition in younger people, relatively little is 
known about its epidemiology (Bhate \& Williams 2013). Acne may be presenting at a younger age because of earlier puberty. It is unclear if ethnicity is truly associated with acne. Black individuals are more prone to post-inflammatory hyperpigmentation and specific subtypes such as 'pomade acne' and persists into the $20 \mathrm{~s}$ and $30 \mathrm{~s}$ in around $64 \%$ and $43 \%$ of individuals, respectively. The heritability of acne is almost $80 \%$ in first-degree relatives and this occurs earlier and is more severe in those with a positive family history (Bhate \& Williams 2013). It is the most common disease of the skin and affects $85 \%$ of teenagers, $42.5 \%$ of men, and $50.9 \%$ of women between the ages of 20 and 30 years (Lolis, Bowe, and Shalita, 2009). While acne is commonly viewed as a disorder of adolescence, it may persist into adulthood and often may present for the first time in adulthood (Kraning and Odland 1979 cited by Kamangar \& Shinkai, 2012). Larger studies evaluating sex differences have shown that acne is more prevalent in girls at younger age ranges, with increasing prevalence in boys as they reach puberty (Aksu et al. 2012). Male subjects also tend to have more severe acne (Aktan, Ozmen, and Sanli, 2000). Following the teenage years, the prevalence in women again tends to be higher than in men. It has been reported by Yahya (2009), that the proportions of acne vulgaris in hospital-based studies of skin disease in Africa have been reported to be $4.6 \%$ in Ghana, $6.7 \%$ in Nigeria (Yahya 2007) and up to $17.5 \%$ in South Africa (Hartshorne, 2003; Yahya, 2009). Acne vulgaris is very common in adolescents in Nigeria, with a prevalence ranging from 35\%-90.7\% (Ogunbiyi, Omigbodun, and Owoaje, 2009) in community-based surveys across the nation; it has also consistently ranked among the ten most common reasons for consultations in dermatologic outpatient clinics in both the northern and southern parts of the country (Yahya, 2009). The role of hormones, particularly as a trigger of sebum production and sebaceous growth and differentiation, is well known. Excess production of hormones, specifically androgens, growth hormone, insulin growth factor1, insulin, Corticotropin releasing hormone, and glucocorticoids, is associated with increased rates of acne development. Acne may be a feature in many endocrine disorders, including polycystic ovary disease, Cushing syndrome, $\mathrm{CAH}$, androgensecreting tumors, and acromegaly (Lolis, Bowe, and Shalita, 2009). Prolactin (PRL) is a peptide hormone produced by the pituitary gland and diverse extra pituitary sites, which triggers activation of various signaling pathways after binding to its prolactin receptor (PRLr) resulting in the activation of specific genes associated with the pleiotropic activities of PLR (Pereira, Lopez-Rincon, Martinez, and Estrada-Chavez, 2015). Prolactin (PRL), also known as luteotropic hormone or luteotropin or lactotrope is a protein that in humans is best known for its role in enabling female mammals to produce milk (Bole-Feysot, and Goffin, Edery, Binart, and Kelly 2013). Also has it been recorded, of prolactin having over three hundred (300) nonlactational functions such as acting in acts in a cytokine-like manner and as an important regulator of the immune system, cell cycle related functions as a growth-, differentiating- and anti-apoptotic factor (Bole-Feysot, Goffin 1998). As a growth factor, involved in the regulation of blood clotting through several pathways and more (Freeman, Kanyicska, Lerant and
Nagy, 2000).

Despite technological advances and an increased degree of sophistication within experimental dermatology, the precise mechanisms of the acne process remain elusive. Many young people especially the adolescents were seen been so curious to find out if the difference in hormonal levels in individual were the main cause of acne vulgaris. Androgens, microbes and other pathogenetic influences are also at work in the development of acne (Strauss et al., 2007; Kurokawa, 2009). However with the relationship of acne to hormones, studies, records and evidences tend to prove the roles of prolactin involved in the pathogenesis of acne.

\section{Aim of the Study}

This study is aimed at assessing serum prolactin levels in individuals with acne vulgaris (test group) in comparison to individuals without acne (control group).

\section{Materials}

1. Questionnaires

2. Five milliliter syringes and tunicate

3. Cotton wools, gloves and ethanol

4. Plaintube containers

5. Prolactin enzyme-linked immunosorbent assay (ELISA) test kit with catalog number: PR234F from CALBIOTECH Company Spring Valley, California, United States.

\section{Methodology}

\subsection{Design}

The study is case control studyaimed at assessment and comparison of serum hormonal levels of prolactin in acne vulgaris individuals and non-acne individuals.

\subsection{Subjects}

A number of sixty (60) subjects were used in this research study; of which thirty (30) were males and 30 were females respectively aged between 18 and 30 (mean age: $24 \pm 3.0$ years). They were all students of College of Health Science Nnamdi Azikiwe University.

\subsection{Groups}

This study is a cross-sectional case-control one that was conducted on two groups. Subjects in each category (male and female) were dived into two groups respectively; The control group consisting of individuals without acne and the test group consisting of individuals with acne having 15 subjects in each respectively.

\subsection{Setting}

The study was conducted on July 2015, at the College of Health Sciences Nnamdi Azikiwe University, Nnewi, 
Anambra State, Nigeria. This study was conducted towards the period of school examinations of the students.

\subsection{Sampling Approach}

Sixty subjects were selected, of which were grouped into 30 males and 30 females. In each of the category of male and female, it was further grouped into control groups of fifteen (15) subjects and test group of 15 subjects respectively. The criteria on which subjects were selected as follows:

\subsection{Inclusion Criteria}

1. Subjects were within the age range of 18-30 years.

2. Subjects under control group were individuals whose skin were void of acne and have no previous case or experience of acne.

3. Subjects under test group were individuals with moderate to severe acne.

4. Menstrual patterns of female subjects.

\subsection{Exclusion Criteria}

1. Individuals who were sick or under any type of medications

2. Obese individuals.

3. Pregnancy and lactation

4. Females in their menstrual periods.

5. Smoking

\subsection{Data Collection Methods}

Questionnaires were used to collect data of subjects such as; age, state of health, medications, menstrual patterns (females). Blood samples of about 3- 4 milliliters were collected from subjects through venous puncture by means of syringes ( $5 \mathrm{ml}$ syringe) and dispensed into plain red-top tube blood sample containers, for collection of serum. The hormonal assay was done using the prolactin ELISA kit (CALBIOTECH Company) and with the ELISA machine at the Nnamdi Azikiwe University Teaching Hospital, Nnewi. Hormonal analysis was carried out immediately after two days of samples collection.

\subsection{Principle of the Prolactin ELISA Test}

The prolactin quantitative test is based on a solid phase sandwich ELISA assay method, based on a streptavidinbiotin principle. The standards, samples and a reagent mixture of Anti-prolactin Enzyme and Biotin conjugates are added into the wells, coated with Streptavidin. Prolactin in the subject's serum forms a sandwich between two highly specific Prolactin antibodies labeled with Biotin and HRP. Simultaneously, the biotinylated antibody is immobilized onto the well through a high affinity Streptavidin-Biotin interaction. Unbound protein and excess biotin/enzyme conjugated reagent are washed off by wash buffer. Upon the addition of substrate, the intensity of colour developed is directly proportional to the concentration of Prolactin in the samples. A standard curve is prepared relating colour intensity to the concentration of the Prolactin.

\subsection{Reagents Materials Provided with the Kit}

1. Micro titer plated coated with Streptavidin with 96 wells

2. Prolactin standards: 6 vials

3. One bottle Enzyme conjugate reagent, $12 \mathrm{ml}$ One bottle TMB reagent, $12 \mathrm{ml}$

4. One bottle Stop solution, $12 \mathrm{ml}$

One bottle 20X Wash concentrate, $25 \mathrm{ml}$.

\subsection{Materials Required But Not Provided}

1. Distilled or deionized water

2. Precision pipettes

3. Disposable pipette tips

4. ELISA reader capable of reading absorbance at $450 \mathrm{~nm}$

5. Absorbance paper or paper towel

6. Graph paper

\subsection{Prolactin Hormonal Assay Reagent Preparation}

$1 \mathrm{X}$ wash buffer was prepared by adding the contents of the bottle $(25 \mathrm{ml}, 20 \mathrm{X})$ to $475 \mathrm{ml}$ of distilled or deionized water and stored at room temperature $\left(18-26^{\circ} \mathrm{C}\right)$. All reagents were allowed to stand at room temperature and were gently mixed before use.

\subsection{Prolactin Assay Procedure}

1. Placethe desired number of coated strips into the holder

2. Pipette $25 \mu \mathrm{l}$ of Prolactin standards, control and patient's sera.

3. Add $100 \mu$ l of enzyme conjugate to all wells.

4. Cover the plate and incubate for 60 minutes at room temperature $\left(18-26^{\circ} \mathrm{C}\right)$.

5. Remove liquid from all wells. Wash wells three times with $300 \mu \mathrm{l}$ of $1 \mathrm{X}$ wash buffer. Blot on absorbance paper or paper towel.

6. Add $100 \mu \mathrm{l}$ of TMB substrate to all wells.

7. Incubate for 15 minutes at room temperature.

8. Add $50 \mu \mathrm{l}$ of stop solution to all wells. Shake the plate gently to mix the solution.

9. Read absorbance of ELISA Reader at $450 \mathrm{~nm}$ within 15 minutes after adding the stopping solution.

10. Checking prolactin standard values on each standard vial which mightvary from lot to lot, the standard curve is constructed by plotting the absorbance for the standards (vertical axis) versus the standard concentrations (horizontal axis) on a linear graph paper and drawing the best curve through the points.

11. The absorbance for controls and unknown samples is read from the curve and recorded.

\subsection{Ethical Considerations}

Ethical approval was granted by the ethical board committee of the Faculty of Basic Medical Sciences Nnamdi Azikiwe University, Okofia, Nnewi, Anambra State, Nigeria. 


\subsection{Statistical Analysis}

The results were collected, tabulated as Mean \pm S.E.M the data were analyzed with T-test analysis using the statistical package for social sciences, version 20.0. The differences were considered significant at $\mathrm{p}<0.05$.

\section{Result}

Table 1. Showing Gender of the Respondents.

\begin{tabular}{lll}
\hline GENDER & FREQUENCY & PERCENTAGE \\
\hline MALES & 30 & 50 \\
FEMALE & 30 & 50 \\
\hline
\end{tabular}

\section{GENDER OF THE RESPONDENTS}

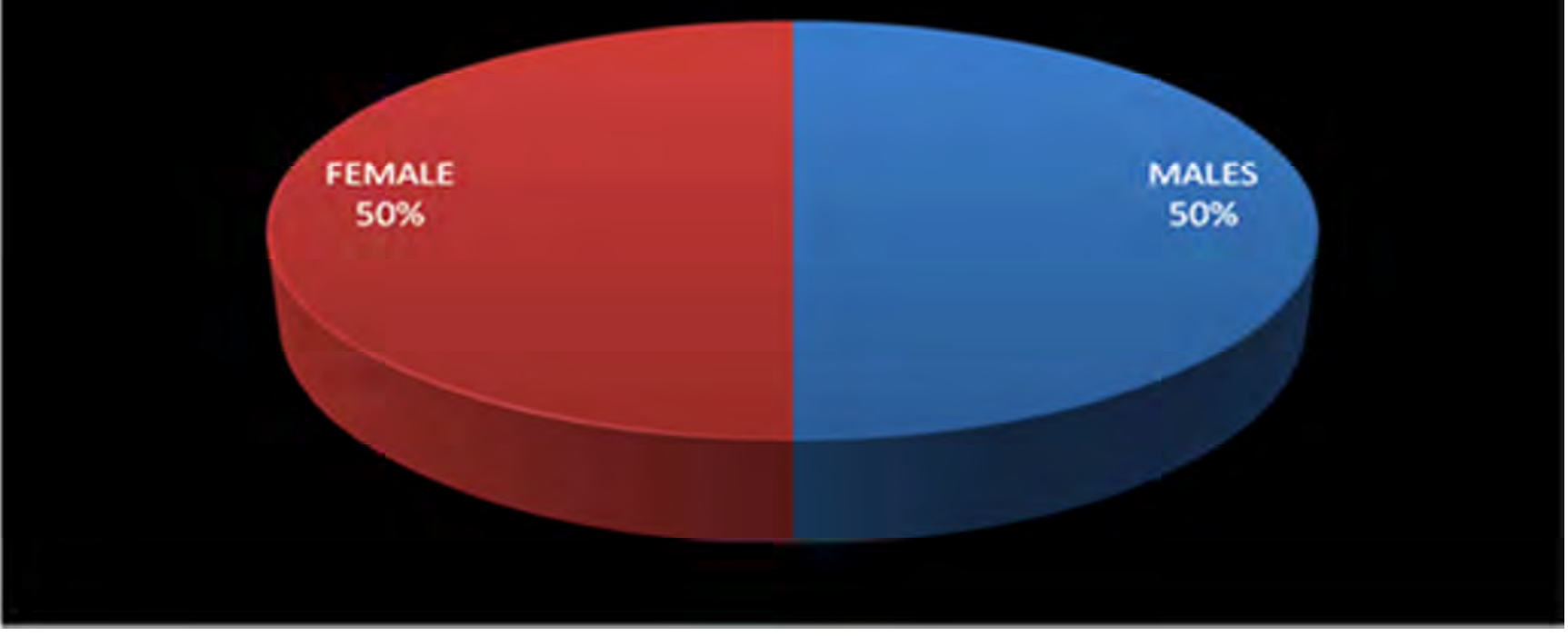

Figure 1. Gender of the respondents.

The gender or respondents indicates the group in which the subjects were grouped into.

Table 2. Unpaired t-test analysis comparing serum prolactin levels of non-acne males with acne males.

\begin{tabular}{llllllll}
\hline P PARAMETER & GROUP & N & MEAN \pm SEM & T-VALUE & DF & P-VALUE & REMARK \\
\hline \multirow{2}{*}{ MALE PROLACTIN } & NON ACNE (CONTROL) & 15 & $8.80 \pm 1.03$ & 1.890 & 28 & 0.069 & Non-significant \\
& ACNE (TEST) & 15 & $12.26 \pm 1.50$ & & & & \\
\hline
\end{tabular}

Table 2 shows t-test prolactin analysis between males' acne and non-acne. The result revealed that when the males acne $(12.26 \pm 1.50)$ were compare to the males non-acne

Table 3. Unpaired t-test analysis comparing serum prolactin levels of non-acne females with acne females.
$(8.80 \pm 1.03)$ there was a non-statistically significant difference $(\mathrm{p}>0.05)$.

\begin{tabular}{lllllll}
\hline \multicolumn{1}{l}{ PARAMETERGROUP } & N & MEAN \pm SEM & T-VALUE & DF & P-VALUE & REMARK \\
\hline FEMALE & NON ACNE (CONTROL) & 15 & $12.92 \pm 1.62$ & 1.870 & 28 & 0.072 \\
PROLACTIN & ACNE (TEST) & 15 & $22.04 \pm 4.59$ & & Non-significant \\
\hline
\end{tabular}

Table 3 shows t-test prolactin analysis of females' acne and non-acne. The results showed that when the females acne $(22.04 \pm 4.59)$ were compared to the females non-acne

$(12.92 \pm 1.62)$ there was a non-statistically significant difference $(\mathrm{p}>0.05)$.

Table 4. Unpaired t-test analysis comparing serum prolactin levels of acne males with acne females.

\begin{tabular}{llllllll}
\hline & TEST GROUPS & N & MEAN \pm SEM & T-VALUE & DF & P-VALUE & REMARK \\
\hline \multirow{2}{*}{ ANALYSIS PROLACTIN } & MALES (ACNE) & 15 & $12.26 \pm 1.50$ & 2.021 & 28 & 0.053 & Non-significant \\
& FEMALES (ACNE) & 15 & $22.04 \pm 4.59$ & & & \\
\hline
\end{tabular}




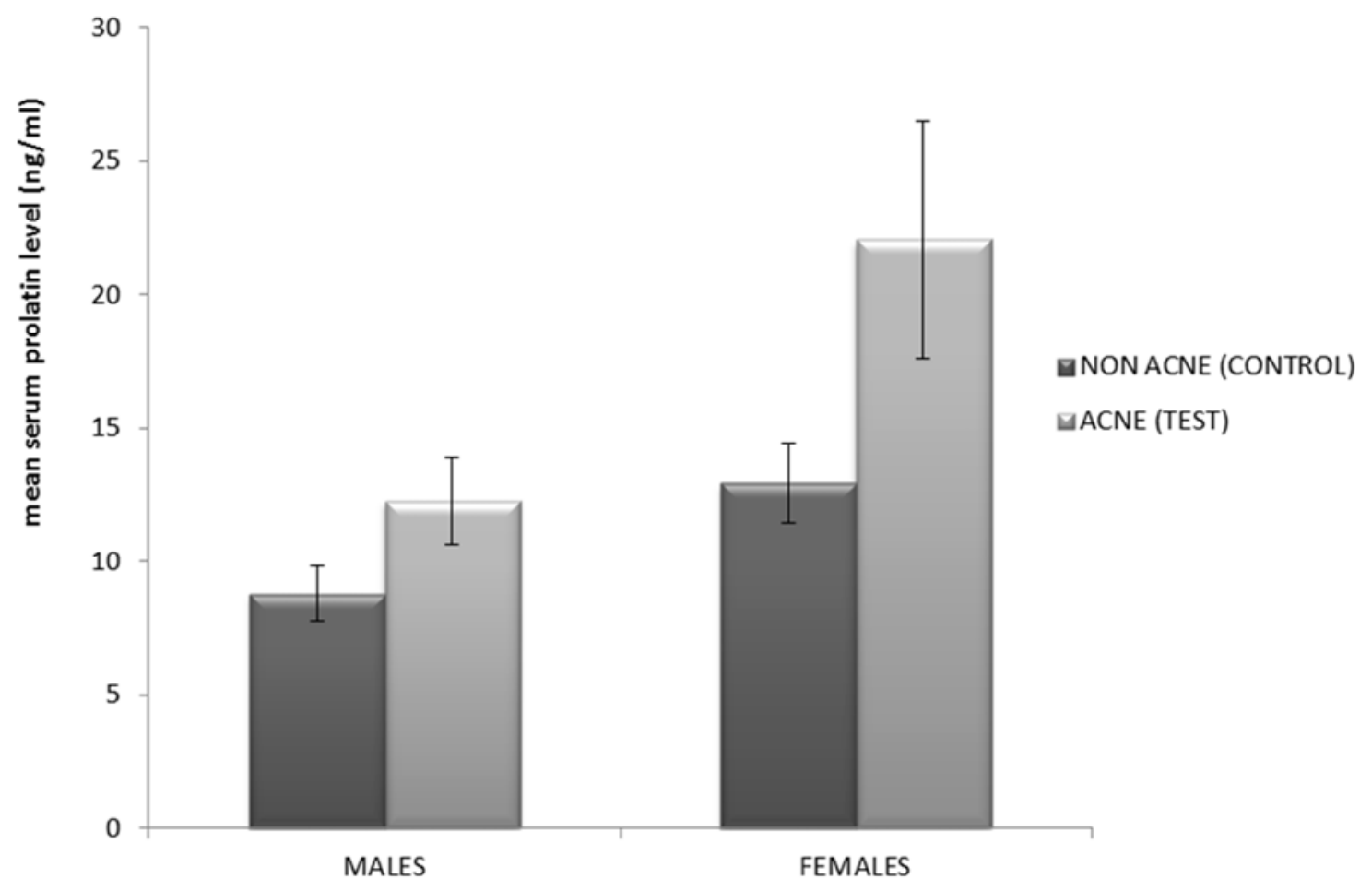

Figure 2. Comparism of serum prolactin level between males and females acne and non-acne students.

Table 4 shows t-test prolactin analysis of acne males and acne females. The results showed that when the acne males $(12.26 \pm 1.50)$ were compared to the acne females
$(22.04 \pm 4.59)$ there was a non-statistically significant difference $(\mathrm{p}>0.05)$.

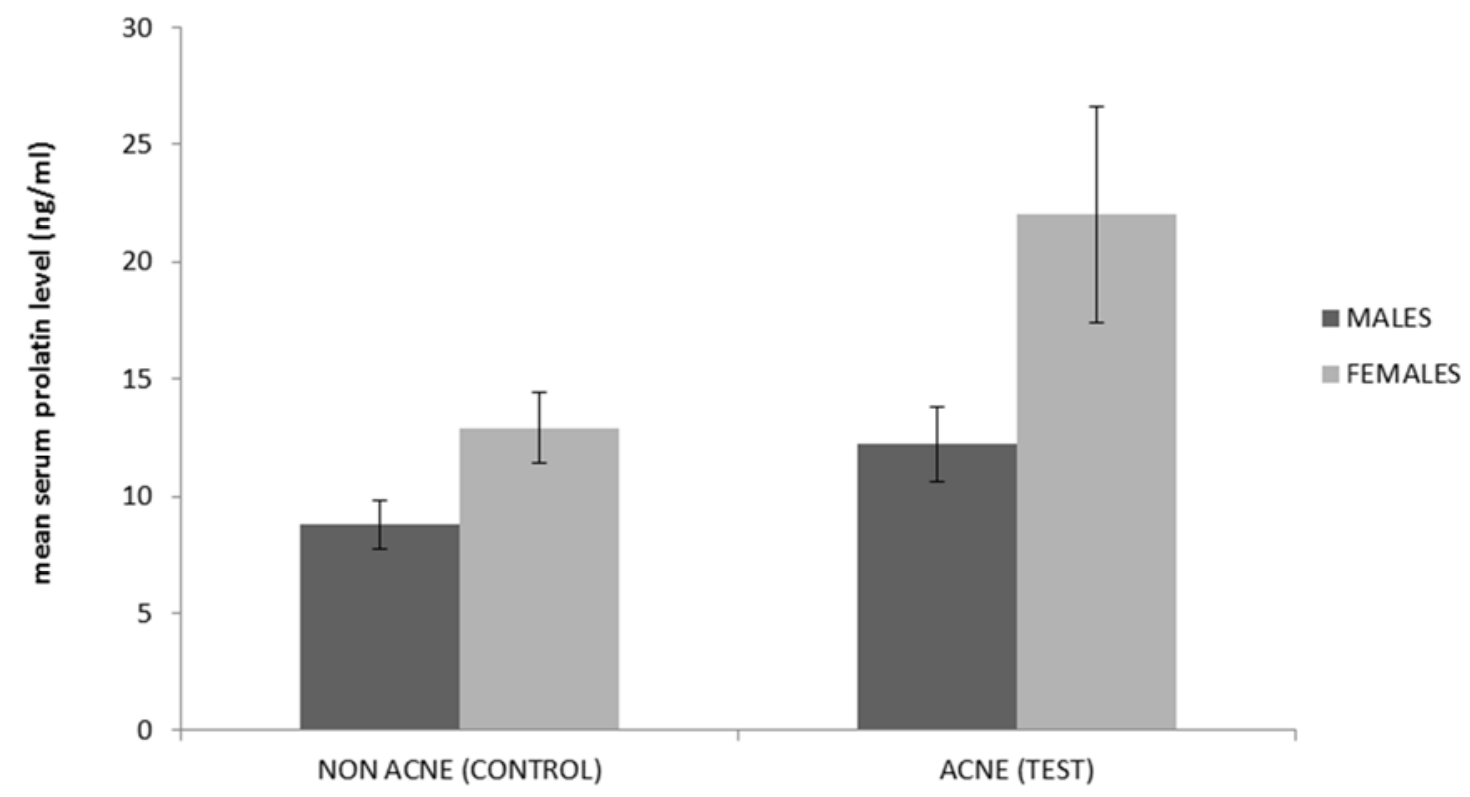

Figure 3. Comparism of serum prolactin level between males and females acne and non-acne students.

Table 5. Unpaired t-test analysis comparing serum prolactin level of non-acne males with non-acne females.

\begin{tabular}{llllllll}
\hline & GROUP 2 & N & MEAN \pm SEM & T-VALUE & DF & P-VALUE & REMARK \\
\hline \multirow{2}{*}{ ANALYSIS } & MALES (NON ACNE) & 15 & $8.81 \pm 1.04$ & 2.135 & 28 & 0.042 & Significant \\
& FEMALES (NON ACNE) & 15 & $12.92 \pm 1.62$ & & & \\
\hline
\end{tabular}

Table 5 shows t-test prolactin analysis of non-acne males and non-acne females. The results showed that when the non- acne males $(8.81 \pm 1.04)$ were compared to the non-acne females (12.92 \pm 1.62$)$ there was a statistically significant 
difference $(\mathrm{p}>0.05)$.

\subsection{Studied Population}

Ages of both the control group and test group in male and female category ranged from $18-30$ years with mean \pm S.D age of $24 \pm 3.0$ years. $53.3 \%$ of the acne subjects of the female category had severe acne and $46.6 \%$ had moderate acne. Percentage of moderate acne for the male acne subjects were $33.3 \%$ while that of severe being $66.6 \%$. Also $40 \%$ percent of female acne subjects confirmed to have irregular menstrual patterns.

\subsection{Laboratory Results}

Males: mean serum prolactin level of acne subjects $(12.26 \pm 1.50)$ was elevated compared to non-acne subjects

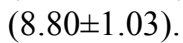

Females: mean serum prolactin level of acne subjects $(22.04 \pm 4.59)$ was elevated compared to non-acne subjects $(12.92 \pm 1.62)$.

\section{Discussion}

From the result above the analysis showed no significant changes between prolactin levels in acne individuals and non-acne individuals of both the male and female categories which is in correspondence with the study of Faghihi et al. in 2000, although the study was a case control study centered on females, however their mean levels showed an elevated increase or rise in comparison. This may be due to the sample size, and specificity of work or occupation of subjects. Also, there was a statistical significant difference between prolactin levels of non-acne females to that of non-acne males, this could be as a result of the normal function of prolactin in the regulation of menstrual cycle for the females.

Also this study was carried out towards the period of school examinations of the students, this could also be a contributing factor of increased prolactin levels more especially in the acne subjects and also the increase severity of acne prevalence among the acne subjects, this is because stress is a main contributing factor in increase prolactin secretion and acne severity (Chiu and Wise, 2003b). Prolactin is a hormone mainly known for its production of breast milk, with its level increasing during the course of pregnancy, very high during pregnancy and also during breastfeeding and also has it been known to have over 300 non-lactational functions and one of which may contribute to the pathogenesis of acne. From research works carried out prolactin however has been observed to maintain and increase high 5 alpha-reductase activity. The enzyme $5 \alpha$-reductase is an enzyme involved in steroid metabolism. It is responsible for the conversion of testosterone into Dihydrotestosterone (DHT). The enzyme is produced in many tissues in both males and females, in the reproductive tract, testes and ovaries, (Liang et al. 1993) skin, seminal vesicles, prostate, epididymis and many organs. DHT increases sebocytes proliferation, sebum production and hyperkeratinization. However, testosterone and DHT are the major androgens that interact with the androgen receptors that are localized in the basal layer of the sebaceous gland and the outer root sheath keratinocytes of the hair follicle.

Factors and conditions which have been observed to increase prolactin levels have also been seen to trigger the development of acne. Such include; breastfeeding, stress (Lennartsson, Kushnir, Bergquist, Billig, andJonsdottir 2012), sexual arousal and orgasm (Krüger et al. 2002), hypo and hyperthyroidism (Cooper, McKelvey, and Sumrada 1979) and several drugs including antipsychotics, antidepressants, opioids (Torre and Falorni 2007).

Prolactin works synergistically with growth hormone, melatonin and leptin. These hormones are elevated while sleeping, particularly slow wave sleep and all of them are pro-inflammatory by stimulating immune activity. Cortisol and catecholamines are lower while sleeping and are antiinflammatory by suppressing immune activity. This results in a highly pro-inflammatory environment during slow wave sleep. Prolactin is quite pro-inflammatory as it promotes immune activation and the production of several proinflammatory cytokines through its action by acting in a cytokine-like manner, thus its contribution to the characteristic feature of acnes. Consistent with its proinflammatory effects, prolactin is associated with some autoimmune diseases. Elevated prolactin is seen in the active phase of some autoimmune diseases and is present before symptoms appear. Elevated prolactin can induce a lupus-like phenotype and $20-30 \%$ of people with lupus have hyperprolactinemia (Jara, Vera-Lastra, Miranda, Alcala, and Alvarez-Nemegyei, 2006). According to a research by Darley et al. in $1982,45 \%$ of adult women with acne were seen to havehyperprolactinemia, which may be responsible for their excessive androgen signaling as androgen levels often fall when hyperprolactinemia is treated (Lobo and Kletzky 1983).

\section{Conclusion}

In the light of the experiment prolactin levels were increased in acne individuals compared to prolactin levels of non-acne individuals with most of acne individuals having their prolactin levels attributed to hyperprolactinemia. With prolactin being implicated with more than 300 functions, high prolactin levels in acne patients could serve as a basis for clinical diagnosis in some certain clinical cases, example infertility and polycystic ovarian syndrome.

\section{Recommendation}

More powerful studies are needed for this research study and also subjects from different specificity of work and occupation should be considered.

\section{References}

[1] Adityan, B. and Thappa, D. M (2009) Profile of Acne Vulgar: A Hospital-Based Study from South India. Indian Journal of Dermatology. Venereol Leprol Vol. 75 pp 272-278. 
[2] Aksu A. E. K., Metntas S., Saracolglu, Z. N., Glurel, G., Sabuncu, I., Arikan, I., and Kalyoncu (2012) Acne: Prevalence and Relationship with Dietary Habits in Eskisehir, Turkey. Journal of European Academy Dermatology. Venereol Vol. 26 PP 1503-1509.

[3] Aktan S, Ozmen E, Sanli B. (2000) Anxiety, depression, and nature of acne vulgaris in adolescents. International Journal of Dermatolgy, Vol. 39 (5) pp 354-7.

[4] Barnes L., Levender, M. M., Fleischer, A. B. and Feldman, S. R (2012) Quality of Life Measures for Acne Patients. Elsevier, Vol. 3 (2) 293-99.

[5] Bhate K, and Williams HC. (2013) Epidemiology of acne vulgaris. British Journal of Dermatology 168 (3), 474-85. doi: $10.1111 / \mathrm{bjd} .12149$

[6] Bole-Feysot, C., Goffin, V., Edery M, Binart N, Kelly PA (1998) Prolactin (PRL) and its Receptor: Actions, Signal Transduction Pathways and Phenotypes Observed in PRL Receptor Knockout Mice. Endocrine Review. Vol. 19: 225268.

[7] Chiu, S. and Wise P. M (2003) Prolactin Receptor mRNA Localization in the Hypothalamus by in situ Hybridization. Journal of Neuroendocrinology, Vol. 6: 191-199.

[8] Cooper TG, McKelvey J, Sumrada R. (1979) Oxalurate transport in Saccharomyces cerevisiae. Journal of Bacteriology 139 (3) 917-23.

[9] Freeman ME, Kanyicska B, Lerant A, Nagy G. (2000) Prolactin: structure, function, and regulation of secretion. American Physiological Society Journals. Physiological Reviews 80 (4): 1523-631.

[10] Hartshone, S. T (2003) Dermatological Disorders in Johannesburg, South Africa. Journal of Clinical and Experimental Dermatology, Vol. 28 PP. 661-665. doi: 10.1046/j.1365-2230.2003.01417.x.

[11] Jara, L. J, Vera-Lastra, O., Miranda, J. M., Alcala, M., and Alvarez-Nemegyei, J. (2001) Prolactin in Human Systemic Lupus Erythematosus. Lupus. 10: 748-56.

[12] Kamangar, F., and Shinkai, K. (2012) Acne in the Adult Female Patient: A Practical Approach. International Journal of Dermatology, Vol. 15 (10): 1162-74. doi: 10.1111/j.13654632.2012.05519.x.

[13] Kruger, O., Ladewig, J., Koster, K., \&Ragg, H. (2002). Widespread Occurrence of Serpin Genes with Multiple Reactive Centre-containing exon Cassettes in Insects and Nematodes. Gene, 293, 97-105. doi: 10.1016/S03781119(02)00697-2.

[14] Kurokawa I, Danby FW, Ju Q, Wang X, Xiang LF, Xia L, Chen W, Nagy I, Picardo M, Suh DH, Ganceviciene R,
Schagen S, Tsatsou F, Zouboulis CC (2009) New developments in our understanding of acne pathogenesis and treatment. Journal of Experimental Dermatology, 18 (10) 82132. doi: 10.1111/j.1600-0625.2009.0089.X.

[15] Lennartsson, A. K., Kushnir, M. M., Bergquist, J., Billig, H., and Jonsdottir, I. H. (2012) Sex Steroid Levels Temporarily Increase in Response to Acute Psychosocial Stress in Healthy Men and Women. International Journal of Psychophysiology. Vol. 84: 246-253.

[16] Liang, P. and Pardee, A. B. (1992) Differential display of eukaryotic messenger RNA by means of the polymerase chain reaction. Science, 257, 967-971.

[17] Lobo RA, Kletzky OA. (1983) Normalization of Androgen and sex Hormone-binding Globulin Levels After Treatment of Hyperprolactinemia. Journal of Clinical Endocrinology Metabolism 56: 562.

[18] Lolis, M. S, Bowe W. P, and Shalita A. R. (2009) Acne and Systemic Disease. Journal of Medical Clinics of North America, Vol. 93 (6): 1161-1181. doi: 10.1016/j.mena.2009.08.008.

[19] Strauss JS, Krowchuk DP, Leyden JJ, Lucky AW, Shalita AR, Siegfried EC, Thiboutot DM, Van Voorhees AS, Beutner KA, Sieck CK, Bhushan R (2007) Guidelines of Care for Acne Vulgaris Management. Journal of American Academic of Dermatology, Vol. 56, pp. 651-63.

[20] Tan JK, Bhate K (2015) A global perspective on the Epidemiology of Acne. British Journal of Dermatology, 172 (1) 3-12. doi: 10.1111/bjd.13462.

[21] Thiboutot, D., Gollnick, H., Bettoli, V., Dréno, B., Kang, S., Leyden, J. J., Shalita, A. R., Lozada, V. T., Berson, D., Finlay, A., Goh, C. L, Herane, M. I, Kaminsky, A. Kubba, R., Layton, A., Miyachi, Y., Perez, M., Martin, J. P., Rasmos-E-Silva, M., See, J. A., Shear, N., and Wolf J. (2009) Global Alliance to Improve Outcomes in Acne. New Insight into the Management of Acne: An Update from the Global Alliance to Improve Outcomes in Acne Group. Journal of American Academic of Dermatology. doi: 10.1016/j.jaad2009.01.019.

[22] Torre, D. L., and Falorni, A. (2007). Pharmacological Causes of Hyperprolactinemia. Journal of Therapeutics and Clinical Risk Management, Vol. 3 (5), 929-951.

[23] Yahya H. (2009) Acne Vulgaris in Nigerian AdolescentsPrevalence, Severity, Beliefs, Perceptions and Practices. International Journal of Dermatology, Vol. 48 (5): 498-505. doi: 10.1111/j.1365-4632.2009.03922.X.

[24] Yahya, H. (2007) Change in Pattern of Skin Disease in Kaduna, North Central Nigeria. International Journal of Dermatology, Vol. 46 pp. 936-943. doi: 10.1111/j.13654632.2007.03218.x. 